\title{
Quality characteristics and antioxidative activity of 'Sulgidduk' added with Elaeagnus multiflora powder
}

\author{
$\mathrm{Ju}-$ Yeon Hong, Wang-Kyu $\mathrm{Oh}^{*}$ \\ Faculty of Herbal Food Cuisine and Nutrition, Daegu Haany University, Gyeongsan 38610, Korea
}

\section{뜰보리수 분말을 첨가한 설기떡의 품질 특성 및 항산화 활성}

\author{
홍주연 · 오왕규* \\ 대구한의대학교 한방식품조리영양학부
}

\begin{abstract}
The purpose of this study was to evaluate the quality and functionality of Elaeagnus multiflora powder for developing a processed food using Elaeagnus multiflora powder. Elaeagnus multiflora 'Sulgidduk' was developed by adding 0, 3, 6, 9 and 12\% Elaeagnus multiflora powder and the physicochemical characteristics of the 'Sulgidduk' were examined. Analysis of the general contents of the 'Sulgidduk' added with Elaeagnus multiflora powder showed that moisture, crude protein, crude lipids and crude ash increased, while the carbohydrate content decreased with increasing amount of added Elaeagnus multiflora powder the $\mathrm{pH}$ also decreased. The Brix value and soluble protein content increased as the amount of Elaeagnus multiflora was increased while the reducing sugar content decreased. The 'Sulgidduk" " $L$ " value decreased, while its " $a$ " and " $b$ " values increased with increasing amount of Elaeagnus multiflora powder and the hardness, adhesiveness, cohesiveness, and chewiness decreased, the polyphenol contents and electron donating ability also increased. On the basis of these results, the preserved quality of 'Sulgidduk' added with Elaeagnus multiflora powder was higher than that of the control 'Sulgidduk'.
\end{abstract}

Key words : Elaeagnus multiflora, powder, 'Sulgidduk', quality characteristics, functionality

서 론

최근 고령화 인구의 증가에 따른 현대인의 건강에 대한 관심 증가와 더불어 생체리듬 조절 및 질병의 치료와 노화 억제 등의 생명활동에 영향을 미치는 천연 식재료 속의 기능성 물질에 대한 관심이 높아지고 있다고 보고하였다 (Park과 Kim, 1992). 이에 따라 천연 식재료 속의 탐색과 기능성 식품 개발에 대한 연구가 활발히 수행되면서 천연 식재료의 기능성 성분과 이에 함유되어 있는 2 차 대사산물 의 생리활성 효과에 대한 연구가 주요 관심사가 되고 있다. 특히 천연식품 중에서 과채류 속에 함유되어 있는 vitamins, carotenoids, flavonoids와 같은 페놀성 화합물들이 다량 존 재하여 항산화성, 항알러지성, 항암성, 콜레스테롤 저하 등의 다양한 생리기능을 갖고 있는 것으로 밝혀짐에 따라 천연식재료를 이용한 항산화제의 개발을 위한 연구가 시 도되고 있다(Ames과 Saul, 1987; Ham 등, 1997; Yu 등, 2006). 따라서 식품도 이젠 맛과 영양을 강조하던 단계에서 인체의 다양한 생리적 기능 항진과 더불어 질병의 예방 및 치료가 가능한 기능성 식품의 발전이 부각되고 있다 (Jan 등, 2013). 또한, 우리나라 식생활 양식 변화로 건강기 능성 식품과 같은 건강식품에 대한 관심이 증가하고 있으 며, 식생활 전반에 걸친 웰빙 개념의 도입으로 떡류가 건강

\footnotetext{
*Corresponding author. E-mail : ok@dhu.ac.kr, Phone : +82-53-819-1592, Fax : +82-53-819-1494

Received 17 October 2019; Revised 16 January 2020; Accepted 11 February 2020.

Copyright (c) The Korean Society of Food Preservation.

This is an Open Access article distributed under the terms of the Creative Commons Attribution Non-Commercial License (http://creativecommons.org/licenses/by-nc/4.0) which permits unrestricted non-commercial use, distribution, and reproduction in any medium, provided the original work is properly cited.
} 
식품이라는 인식이 높아지고 있어 전통 떡에 대한 관심 및 수요가 증가하고 있다(Hyun 등, 2005; Park, 2008).

떡은 곡물을 가루로 하여 물과 반죽하여 쪄서 만든 음식 으로 제조방법과 첨가 재료에 따라 찌는 떡, 치는 떡, 지지 는 떡, 삶는 떡으로 구분된다. 떡은 견과류, 채소, 과일류, 버섯, 꽃, 뿌리, 나뭇잎 등 첨가재료를 달리할 수 있기 때문 에 영양학적으로 우수한 식품일 뿐 아니라 첨가재료로부 터 오는 색깔이나 모양도 다양해 외관도 훌륭하며, 생리적 기능이 있는 여러 가지 재료들을 첨가하면 건강식품으로 도 손색이 없는 고유한 전통식품이다(Cha와 Lee, 2001; $\mathrm{Ryu}$ 등, 2005). 건강기능성 설기떡 연구를 살펴보면 레드비 트분말(Ko와 Jeong, 2018), 꾸지뽕열매분말(Choi와 Choi, 2018), 복분자 잎(Rha와 Kang, 2014), 더덕 분말(Lee, 2019), 떫은 감 분말(Kim 등, 2006), 흑미발효미강분말(Shin과 Chung, 2018) 등 생리활성을 가진 기능성 부재료를 분말 형태로 첨가한 설기떡의 품질특성에 관한 연구가 이루어 지고 있다. 따라서 기존에 건강 기능성이 강화된 설기떡의 다양한 선행연구가 있으나, 뜰보리수 분말을 첨가한 떡의 연구는 미비한 상황이다.

또한, 과거의 떡은 선조들의 삶에서 빼놓을 수 없었을 정도의 최고의 음식으로 우대받아 왔으나 현대 사회에서 의 떡은 식생활의 서구화와 핵가족화, 식품공업의 발달, 제과-제빵의 기술의 발달로 인해 설 자리를 잃어가고 있 어 떡에 대한 관심을 높이기 위해 재료와 분량의 표준화, 공정에 있어 간소화, 포장의 과학화 등을 통해 떡을 쉽게 접할 수 있는 기반을 마련해 주는 것이 필요할 것으로 생각된다(Lim, 2011).

뜰보리수(Elaeagnus multiflora Thunb.)는 보리수나무과 (Elaeagnaceae) 보리수나무속(Elaeagnus)의 식물로서 국내 에서 주로 관상용 또는 과수로 재배되고 있다(Cho, 1989). 뜰보리수 열매의 맛은 다소 떫은맛과 단맛을 가지고 있으 며 식용이 가능하며, 농약이나 화학비료를 주지 않고 특별 한 관리가 없어도 잘 성장하고 무농약, 유기농 과수로 재배 할 수 있다(Ko와 Jeon, 2003). 뜰보리수 열매는 glucose와 fructose 등 6종의 유리당을 함유하고 있고, citric acid와 acetic acid 등의 유기산의 함량도 높고, cystine 및 phenylalanine인 필수아미노산도 함유하고 있으며, $\mathrm{K}, \mathrm{Ca}$, $\mathrm{Mg}$ 등의 무기질과 비타민 C도 함유하고 있으며, 뜰보리수 열매의 열수 및 에탄올 추출물에는 폴리페놀 함량 및 플라 보노이드 함량도 우수하고, 추출물의 농도가 증가할수록 항산화 활성도 높게 나타났다(Hong, 2008). 뜰보리수는 한 방에서 오장을 보익하고 번열(煩熱)과 소갈(消渴)을 없애 며, 설사와 피나는 것을 멎게 하고, 소화불량, 골수염, 부종, 생리불순, 치질을 낫게 한다고 알려져 있다(Park, 2004). 뜰보리수 열매는 한방에서 약재로 소량 사용되고 있지만, 식품으로서의 이용 증대가 필요할 뿐만 아니라, 그에 대한
다양한 연구도 거의 이루어지지 않고 있다.

따라서 본 연구는 우수한 생리활성을 가진 뜰보리수를 동결건조하여 분말화 한 다음 뜰보리수 분말 첨가비율을 달리하여 뜰보리수 설기떡을 제조한 후 뜰보리수 첨가 설기떡의 일반성분, 색도, 조직감, 총 폴리페놀 함량, 전자 공여능 등 품질특성과 항산화 활성도를 조사하여 뜰보리 수 설기떡의 기능성 향상과 더불어 뜰보리수를 이용한 기능성 식품소재로서의 활용도를 높이는데 기초자료로 활용하고자 한다.

\section{재료 및 방법}

\section{실험 재료}

본 연구의 재료는 경산지역 농가에서 재배한 완숙 상태 의 뜰보리수를 2018년 6월 초 수확하여 사용하였다. 뜰보 리수는 흐르는 물에 깨끗이 씻은 후 씨를 제거하고 작게 절단하여 $-80^{\circ} \mathrm{C}$ 급속냉동고(MDF-U52V, SANYO, Tokyo, $\mathrm{Japan})$ 에서 24 시간 급속 냉동 후 $-90^{\circ} \mathrm{C}$ 로 맞추어진 진공동 결건조기(FD-8512, ILSHIN, Namyangju, Korea)에서 동결 건조를 하였다. 건조된 뜰보리수는 분쇄기(AMS330TS, Shinil, Seoul, Korea)로 분쇄하여 $40 \mathrm{mesh}$ 체를 통과시킨 분말을 $-80^{\circ} \mathrm{C}$ 에서 냉동보관하며 실험에 사용하였다. 그 외 쌀(BM co., Gangwon), 소금(Daesang, Gyeonggido), 물 (Jeju province development co., Jeju), 백설탕(CJ Cheiljedang, Inchen)은 대형마트에서 구입하여 사용하였다.

\section{뜰보리수를 첨가한 설기떡의 제조}

뜰보리수를 첨가한 설기떡의 제조는 선행연구를 바탕 으로 여러 차례 예비실험을 거쳐 Table 1 의 재료배합비로 제조하였다. 뜰보리수 분말을 첨가한 설기떡의 제조는 쌀 가루 $100 \mathrm{~g}$ 을 기준으로 설탕 $13 \%$, 소금 $1.3 \%$, 물 $15 \%$ 를 첨가하였고, 뜰보리수 분말의 첨가량은 쌀가루 기준 $0 \%$, $3 \%, 6 \%, 9 \%, 12 \%$ 를 각각 첨가하여 제조하였다. 쌀은 씻어 12 시간 침지한 다음 쌀가루를 만들었고, 뜰보리수 분말과 소금을 혼합한 후 체에 내린 설탕을 첨가하여 제조하였다.

설기떡 제조는 스텐레스 스틸 이중 찜 솥을 사용하였으 며, 틀에 면보자기를 깔고, 떡가루를 넣은 후 김이 오르고 난 후 15 분간 가열하며, 5 분간 뜸을 들였다. 찐 설기떡은 꺼내어 60 분간 방냉한 후 시료로 사용하였다.

\section{일반성분}

뜰보리수 분말과 뜰보리수 첨가 설기떡의 일반성분 분 석은 AOAC 방법(AOAC, 1990)에 따라 행하였다. 즉, 수분 함량은 적외선 수분 측정기(Presisa HA-300, Dietikon, Switzerland)를 이용하여 측정하였으며, 조단백질의 함량 은 Kjeldahl 법으로 조단백 자동분석장치(Foss Kjeltec ${ }^{\mathrm{TM}}$ 
Table 1. Preparation formulas for 'Sulgidduk' added with different amounts of Elaeagnus multiflora powder

\begin{tabular}{|c|c|c|c|c|c|}
\hline \multirow{2}{*}{ Ingredients (g) } & \multicolumn{5}{|c|}{ 'Sulgidduk' with Elaeagnus multiflora powder $(\%)^{1)}$} \\
\hline & SEP0 & SEP3 & SEP6 & SEP9 & SEP12 \\
\hline Rice flour & 200 & 194 & 188 & 182 & 176 \\
\hline Elaeagnus multiflora powder & 0 & 6 & 12 & 18 & 24 \\
\hline Water & 60 & 60 & 60 & 60 & 60 \\
\hline Sugar & 26 & 26 & 26 & 26 & 26 \\
\hline Salt & 2.6 & 2.6 & 2.6 & 2.6 & 2.6 \\
\hline
\end{tabular}

${ }^{1)}$ SEP0, 'Sulgidduk' added with 0\% Elaeagnus multiflora powder; SEP3, Sulgidduk added with 3\% Elaeagnus multiflora powder; SEP6, 'Sulgidduk' added with $6 \%$ Elaeagnus multiflora powder; SEP9, 'Sulgidduk' added with $9 \%$ Elaeagnus multiflora powder; SEP12, 'Sulgidduk' added with $12 \%$ Elaeagnus multiflora powder.

2300, FOSS, Höganäs, Sweden)로 측정하였다. 조지방 함량 은 Soxhlet법에 준하여 측정하였다. 조회분 함량은 직접 회화법으로 측정하였다. 탄수화물 함량은 시료 전체 $100 \%$ 으로 하여 수분, 조단백질, 조지방, 조회분 함량을 감한 것을 탄수화물 함량(\%)으로 하였다.

\section{$\mathrm{pH}$ 및 당도}

뜰보리수 분말과 뜰보리수 첨가 설기떡의 $\mathrm{pH}$ 는 시료 5 $\mathrm{g}$ 에 증류수 $50 \mathrm{~mL}$ 를 첨가하여 마쇄기로 1 분간 마쇄하고, 실온에서 1시간 보관 후 $\mathrm{pH}$ meter(HM 25R, TOA-DKK, Tokyo, Japan)를 이용하여 측정하였다. 뜰보리수 분말과 뜰 보리수 첨가 설기떡의 당도 측정은 시료 $5 \mathrm{~g}$ 에 증류수 50 $\mathrm{mL}$ 를 첨가하여 마쇄기로 1 분간 마쇄하고, 실온에서 1 시간 보관 후 당도계를 이용하여 측정한 후 ${ }^{\circ} \mathrm{Brix}$ 로 표시하였다.

\section{수용성 단백질}

뜰보리수 분말과 뜰보리수 첨가 설기떡의 수용성 단백 질은 시료 $50 \mathrm{~g}$ 에 증류수 $200 \mathrm{~mL}$ 를 가하여 마쇄한 후 3,000 $\mathrm{rpm}$ 에서 10 분간 원심분리하고, 상층액만 여과지(Whatman No. 4)로 여과한 뒤 $250 \mathrm{~mL}$ 로 정용하였다. 수용성 단백질 의 함량은 Lowry 등의 방법(Lowry 등, 1951)에 따라 측정하 였다. 즉, 시료 $0.2 \mathrm{~mL}$ 를 시험관에 취하고 혼합시약 $(\mathrm{A}: \mathrm{B}=50: 1)$ 을 $1 \mathrm{~mL}$ 첨가하여 $30^{\circ} \mathrm{C}$ 에서 10 분간 반응시켰다. 여기에 $0.1 \mathrm{~mL}$ Folin-Ciocalteu's phenol reagent를 첨가한 뒤 다시 실온에서 30 분간 반응시키고 분광광도계(UV2001, Hitachi, Tokyo, Japan)를 사용하여 $750 \mathrm{~nm}$ 에서 흡광 도를 측정하였다. Bovine serum albumin(Sigma Chemical $\mathrm{Co} ., \mathrm{MO}, \mathrm{USA}$ )으로 검량선을 작성하여 검량선에 의해 단 백질의 함량을 산출하여 나타내었다.

\section{환원당 함량}

뜰보리수 분말과 뜰보리수 첨가 설기떡의 환원당 함량
은 시료 $50 \mathrm{~g}$ 에 증류수 $200 \mathrm{~mL}$ 를 가하여 마쇄한 후 3,000 $\mathrm{rpm}$ 에서 10 분간 원심분리하고, 상층액만 여과지(Whatman No. 4)로 흡입하고 여과한 뒤 $250 \mathrm{~mL}$ 로 정용하였다. 환원 당 함량은 Somogi-Nelson법(Nelson, 1994)에 따라 측정하 였다. 즉, 시료액 $1 \mathrm{~mL}$ 에 시약 $\mathrm{A}$ 액(무수 $\mathrm{Na}_{2} \mathrm{HPO}_{4} 25 \mathrm{~g}$, Rochelle염 $25 \mathrm{~g}, \mathrm{NaHCO}_{3} 20 \mathrm{~g}$, 무수 $\mathrm{Na}_{2} \mathrm{SO}_{4} 200 \mathrm{~g}$ 을 증류수 $1 \mathrm{~L}$ 에 용해한 액)과 시약 $\mathrm{B}$ 액 $\left(\mathrm{CuSO}_{4} \cdot 5 \mathrm{H}_{2} \mathrm{O} 30 \mathrm{~g}\right.$ 과 4방울 의 진한 황산을 첨가한 증류수 $200 \mathrm{~mL}$ 에 용해한 액)을 $25: 1$ 로 혼합한 액을 $0.5 \mathrm{~mL}$ 첨가하여 20 분간 가열한 뒤 냉각시켰다. 그런 다음 $\mathrm{C}$ 액(store at $37^{\circ} \mathrm{C} /$ day-ammonium molybdate $\left(\mathrm{NH}_{4}\right)_{6} \mathrm{Mo}_{7} \mathrm{O}_{24} \cdot 4 \mathrm{H}_{2} \mathrm{O} 25 \mathrm{~g}$ 을 진한 황산 $21 \mathrm{~mL}$ 를 포함하는 증류수 $450 \mathrm{~mL}$ 에 용해하고 sodium arsenate dibasic $\left(\mathrm{Na}_{2} \mathrm{HAsO}_{4} \cdot 7 \mathrm{H}_{2} \mathrm{O}\right) 3 \mathrm{~g}$ 을 증류수 $25 \mathrm{~mL}$ 에 용해한 후 혼합한 액)을 $1 \mathrm{~mL}$ 를 첨가해서 실온에서 방치 후 증류수 $5 \mathrm{~mL}$ 를 혼합해서 분광광도계(UV-2001, Hitachi, Tokyo, Japan)를 사용하여 $520 \mathrm{~nm}$ 에서 흡광도를 측정하였다. 환원 당 산출은 glucose 검량선에 의해 glucose의 함량을 산출하 여 환원당 함량으로 나타내었다.

\section{색도 측정}

뜰보리수 설기떡의 색도 측정은 colormeter(CM-3600d, Minolta, Tokyo, Japan)를 사용하여 측정하였으며, 이것을 Hunter 값 즉, L(lightness), a(redness), b(yellowness)로 나타 내었다. 이때 사용한 표준 백색판(standard plate)은 기기의 사용법에 따라 값을 5 회 반복 측정하였으며 평균값으로 나타내었다.

\section{조직감 측정}

뜰보리수 설기떡의 조직감 측정은 rheometer(COPAC100 II, Sun Scientific, Tokyo, Japan)를 사용하여 측정하였 다. 측정조건에서 test type은 mastication test, distance $50 \%$, plunger diameter $10 \mathrm{~mm}$, adaptor type round, table speed 60 
$\mathrm{mm} / \mathrm{s}$, load cell(max) $2 \mathrm{~kg}$ 의 조건으로 5 회 반복 측정하였다. 뜰보리수 설기떡은 일정한 크기 $3 \mathrm{~cm} \times 3 \mathrm{~cm} \times 2 \mathrm{~cm}$ 로 하여 시료 중심부에 2회 연속 압착하였을 때 얻어지는 값을 산출하여 경도(hardness), 탄력성(springiness), 응집성 (cohesiveness), 씹힘성(chewiness), 부착성(adhesiveness)을 5 회 반복 측정하여 평균값으로 나타내었다.

\section{폴리페놀 함량}

뜰보리수 분말과 뜰보리수 첨가 설기떡의 총 폴리페놀 함량은 Folin-Denis법(Singleton과 Rossi, 1965)으로 측정하 였다. 즉, 시료를 $10 \mathrm{mg} / \mathrm{mL}$ 농도로 증류수에 녹인 다음 $0.2 \mathrm{~mL}$ 를 시험관에 취하고 증류수를 가하여 $2 \mathrm{~mL}$ 로 만든 후 여기에 $0.2 \mathrm{~mL}$ Folin-Ciocalteu's phenol reagent를 첨가하 여 잘 혼합한 후 3 분간 실온에 방치하였다. 정확히 3 분 후 $\mathrm{Na}_{2} \mathrm{CO}_{3}$ 포화용액 $0.4 \mathrm{~mL}$ 를 가하여 혼합하고 증류수를 첨가하여 $4 \mathrm{~mL}$ 로 만든 후 실온에서 1 시간 방치하여 분광광 도계(UV-2001, Hitachi, Tokyo, Japan)를 이용하여 $725 \mathrm{~nm}$ 에서 흡광도를 측정하였다. 이때 총 폴리페놀 화합물은 tannic acid(Sigma Aldrich Co., MO, USA)를 이용하여 작성 한 표준곡선으로부터 뜰보리수 분말과 뜰보리수 분말을 첨가한 설기떡에 함유된 총 폴리페놀 화합물 함량을 산출 하였다.

\section{전자공여능 측정}

뜰보리수 분말과 뜰보리수 첨가 설기떡의 전자공여능 은 Blois 등의 방법(Blois, 1958)에 준하여 각 시료의 1,1-diphenyl-2-picryl hydrazyl(DPPH)에 대한 전자공여 효 과로써 시료의 환원력을 측정하였다. 즉 시료 $2 \mathrm{~mL}$ 에 0.2 $\mathrm{mM} \mathrm{DPPH}$ 용액 $1 \mathrm{~mL}$ 를 가하고, 10 초간 vortex mixing 후 $37^{\circ} \mathrm{C}$ 에서 30 분간 반응시킨 다음 이 반응액을 분광광도계 (UV-2001, Hitachi, Tokyo, Japan)를 사용해서 $517 \mathrm{~nm}$ 에서
흡광도를 측정하였다. 대조구는 천연 항산화제인 L-ascorbic acid를 사용하였고, 아래와 같이 시료첨가구와 무첨가구의 흡광도의 차이를 백분율(\%)로 표시하여 전자 공여능으로 나타내었다.

Electron donating ability $(\%)=[1-(\mathrm{S}-\mathrm{B}) / \mathrm{C}] \times 100$

$\mathrm{S}$ : sample 첨가구의 흡광도

B: blank의 흡광도

C: control(시료 무첨가구)의 흡광도

\section{통계처리}

뜰보리수 분말과 뜰보리수 첨가 설기떡의 결과는 모든 실험을 3회 이상 반복 실시하였고, 평균 \pm 표준편차로 표시 하였다. 각 실험결과는 SPSS 23.0 통계프로그램(SPSS Inc, Chicago, IL, USA)을 이용하여 일원배치 분산분석 One-way ANOVA(Analysis of variance)와 Duncan's multiple range test 실시하여 $\mathrm{p}<0.05$ 에서 유의성을 검증하고, 분석하였다.

\section{결과 및 고찰}

\section{일반성분의 변화}

본 연구에 사용한 동결건조시킨 뜰보리수 분말과 뜰보 리수 분말의 첨가량을 $0 \%, 3 \%, 6 \%, 9 \%, 12 \%$ 로 제조한 설기떡의 일반성분은 Table 2 와 같다. 뜰보리수 분말의 수분함량은 $5.81 \%$, 탄수화물 함량 $82.52 \%$, 조단백질 함량 $4.92 \%$, 조지방 함량이 $3.15 \%$, 조회분 함량은 $3.60 \%$ 이었고, 뜰보리수 분말을 첨가한 설기떡에 사용한 쌀가루의 수분 함량은 $33.4 \%$ 이었다. 뜰보리수 분말의 첨가량을 달리한 설기떡의 수분함량은 $39.12-42.53 \%$ 로 뜰보리수 분말의 첨가량이 증가할수록 수분함량은 다소 증가함을 보였는 데, 이러한 결과는 더덕분말 첨가량을 달리한 설기떡의

Table 2. The content of general components of Elaeagnus multiflora powder and 'Sulgidduk' added with Elaeagnus multiflora powder

\begin{tabular}{ccccccc}
\hline \multirow{2}{*}{$\begin{array}{c}\text { Components } \\
\end{array}$} & $\begin{array}{c}\text { Elaeagnus multiflora } \\
\text { powder }\end{array}$ & \multicolumn{3}{c}{ 'Sulgidduk' added with Elaeagnus multiflora powder $^{1)}$} \\
\cline { 3 - 7 } Moisture & $5.81 \pm 0.04^{2)}$ & $39.12 \pm 0.33^{\mathrm{e} 3)}$ & $39.85 \pm 0.16^{\mathrm{d}}$ & $40.61 \pm 0.27^{\mathrm{c}}$ & $41.26 \pm 0.22^{\mathrm{b}}$ & $42.53 \pm 0.41^{\mathrm{a}}$ \\
Carbohydrate & $82.52 \pm 0.07$ & $58.83 \pm 0.23^{\mathrm{a}}$ & $57.87 \pm 0.15^{\mathrm{b}}$ & $57.00 \pm 0.24^{\mathrm{c}}$ & $56.26 \pm 0.21^{\mathrm{d}}$ & $54.88 \pm 0.23^{\mathrm{e}}$ \\
Crude protein & $4.92 \pm 0.02$ & $1.31 \pm 0.20^{\mathrm{a}}$ & $1.53 \pm 0.06^{\mathrm{a}}$ & $1.57 \pm 0.18^{\mathrm{a}}$ & $1.60 \pm 0.14^{\mathrm{a}}$ & $1.63 \pm 0.20^{\mathrm{a}}$ \\
Crude lipid & $3.15 \pm 0.14$ & $0.07 \pm 0.02^{\mathrm{a}}$ & $0.05 \pm 0.01^{\mathrm{a}}$ & $0.06 \pm 0.01^{\mathrm{a}}$ & $0.07 \pm 0.04^{\mathrm{a}}$ & $0.08 \pm 0.01^{\mathrm{a}}$ \\
Crude ash & $3.60 \pm 0.10$ & $0.67 \pm 0.12^{\mathrm{a}}$ & $0.70 \pm 0.21^{\mathrm{a}}$ & $0.76 \pm 0.33^{\mathrm{a}}$ & $0.81 \pm 0.35^{\mathrm{a}}$ & $0.88 \pm 0.21^{\mathrm{a}}$ \\
\hline
\end{tabular}

${ }^{1)}$ See the preparation formulas for 'Sulgidduk' in Table 1.

2) All value are expressed as Mean $\pm \mathrm{SD}$ of triplicate determinations.

${ }^{3}$ Different superscripts letters within the row are significantly different at $\mathrm{p}<0.05$ by Duncan`s multiple range test. 
품질특성(Lee, 2019) 연구에서 더덕분말 첨가량이 증가할 수록 설기떡의 수분함량이 증가함을 보였고, 울금분말을 첨가한 설기떡의 품질특성(Seo와 Chung, 2014) 연구에서 도 울금 분말 첨가량이 증가할수록 설기떡의 수분함량은 증가한다는 연구결과와 유사한 경향이었다. 뜰보리수 설 기떡의 탄수화물 함량은 전체적으로 $54.55-58.83 \%$ 로 뜰 보리수 분말 첨가량이 증가할수록 감소함을 보였고, 조단 백질의 함량은 $1.31-1.63 \%$ 로 뜰보리수 분말 첨가량이 증 가할수록 증가함을 보였다. 조지방의 함량은 $0.05-0.08 \%$, 조회분의 함량은 $0.67-0.88 \%$ 로 뜰보리수 분말 첨가량이 증가할수록 조지방과 조회분 함량은 증가함을 보였으나 유의적인 차이는 보이지 않았다.

\section{$\mathrm{pH}$ 및 당도}

뜰보리수 분말과 뜰보리수 분말을 첨가한 설기떡의 $\mathrm{pH}$ 및 당도 측정 결과는 Table 3 과 같다. 뜰보리수 설기떡에 사용한 뜰보리수 분말의 $\mathrm{pH}$ 는 3.42 이고, 쌀가루의 $\mathrm{pH}$ 는 6.17 이었다. 뜰보리수 분말의 첨가량을 달리한 설기떡의 $\mathrm{pH}$ 측정 결과, 뜰보리수 분말 무첨가군의 경우 5.35 , 뜰보 리수 첨가군에서는 뜰보리수 분말 $3 \%, 6 \%, 9 \%, 12 \%$ 로 첨가한 경우 $4.57,4.40,4.31,4.24$ 로 뜰보리수 분말의 첨가 량이 증가할수록 $\mathrm{pH}$ 는 감소함을 보여 산성이 강해졌다. 이와 같은 결과는 Lee 등(2008)의 토마토 분말을 첨가한 설기떡 연구에서 대조군은 5.84이었으며, 토마토 분말의 첨가량이 증가할수록 설기떡의 $\mathrm{pH}$ 는 $5.07(2 \%), 4.96(4 \%)$, $4.55(6 \%), 4.28(8 \%)$ 로 낮아짐을 보였고, Joung(2004)의 백 년초 설기떡 연구에서도 백년초 분말의 첨가량이 증가할 수록 설기떡의 $\mathrm{pH}$ 는 감소함을 보여 본 연구와 유사한 경향 이었다.

Table 3. pH and Brix content of Elaeagnus multiflora powder and 'Sulgidduk' added with Elaeagnus multiflora powder

\begin{tabular}{ccc}
\hline $\begin{array}{c}\text { 'Sulgidduk' added } \\
\text { with Elaeagnus } \\
\text { multiflora powder }{ }^{1)}\end{array}$ & $\mathrm{pH}$ & ${ }^{\circ}$ Brix \\
\hline SEP0 & $5.35 \pm 0.00^{2) \mathrm{a} 3)}$ & $10.27 \pm 0.01^{2) \mathrm{d} 33}$ \\
SEP3 & $4.57 \pm 0.01^{\mathrm{b}}$ & $10.01 \pm 0.01^{\mathrm{e}}$ \\
SEP6 & $4.40 \pm 0.00^{\mathrm{c}}$ & $10.40 \pm 0.00^{\mathrm{c}}$ \\
SEP9 & $4.31 \pm 0.00^{\mathrm{d}}$ & $10.82 \pm 0.00^{\mathrm{b}}$ \\
SEP12 & $4.24 \pm 0.01^{\mathrm{e}}$ & $11.03 \pm 0.01^{\mathrm{a}}$ \\
$\begin{array}{c}\text { Elaeagnus multiflora } \\
\text { powder }\end{array}$ & $3.42 \pm 0.01$ & $12.50 \pm 0.00$ \\
\hline
\end{tabular}

\footnotetext{
${ }^{1)}$ See the preparation formulas for 'Sulgidduk' in Table 1 .

${ }^{2)}$ All value are expressed as Mean $\pm \mathrm{SD}$ of triplicate determinations.

${ }^{3)}$ Different superscripts letters within the column are significantly
} different at $\mathrm{p}<0.05$ by Duncan`s multiple range test.
뜰보리수 분말을 첨가한 설기떡에 사용한 뜰보리수 분 말의 당도는 $12.50{ }^{\circ} \mathrm{Brix}$ 이었고, 뜰보리수 분말 무첨가 설 기떡에서 $10.27{ }^{\circ} \mathrm{Brix}$, 뜰보리수 분말 $3 \%$ 첨가군은 10.01 ${ }^{\circ} \mathrm{Brix}$, 뜰보리수 분말 $12 \%$ 첨가군은 $11.03{ }^{\circ} \mathrm{Brix}$ 으로 뜰보 리수 분말의 첨가량이 증가할수록 설기떡의 당도는 다소 증가함을 보였다. 이와 같은 결과는 뜰보리수 열매 분말의 당도가 높아 뜰보리수 분말의 첨가량이 증가할수록 설기 떡의 당도도 증가한 것으로 생각된다.

\section{수용성 단백질 및 환원당 함량}

뜰보리수 분말과 뜰보리수 분말을 첨가한 설기떡의 수 용성 단백질 및 환원당 함량은 Table 4와 같다. 뜰보리수 설기떡에 첨가한 뜰보리수 분말의 수용성 단백질 함량은 $2.31 \mathrm{~g} / 100 \mathrm{~g}$ 이었고, 뜰보리수 분말의 첨가량을 달리한 설 기떡의 수용성 단백질 함량은 $0.12-0.52 \mathrm{~g} / 100 \mathrm{~g}$ 으로 뜰보 리수 분말의 첨가량이 증가할수록 수용성 단백질의 함량 은 증가함을 보였다. 뜰보리수 분말 무첨가군에서 수용성 단백질 함량이 $0.12 \mathrm{~g} / 100 \mathrm{~g}$ 으로 가장 낮았으며, 뜰보리수 분말 $3 \%$ 첨가군에서는 $0.16 \mathrm{~g} / 100 \mathrm{~g}$, 뜰보리수 분말 $6 \%$ 첨가군에서는 $0.25 \mathrm{~g} / 100 \mathrm{~g}$, 뜰보리수 분말 $9 \%$ 첨가군에서 는 $0.37 \mathrm{~g} / 100 \mathrm{~g}$, 뜰보리수 분말 $12 \%$ 첨가군에서는 0.52 $\mathrm{g} / 100 \mathrm{~g}$ 으로 수용성 단백질 함량이 높았다.

뜰보리수 설기떡에 첨가한 뜰보리수 분말의 환원당 함 량은 $5.48 \mathrm{~g} / 100 \mathrm{~g}$ 이었고, 뜰보리수 분말의 첨가량을 달리 한 설기떡의 환원당 함량 결과는 $3.75-5.01 \mathrm{~g} / 100 \mathrm{~g}$ 으로 도토리 분말의 첨가량이 증가할수록 환원당 함량은 감소 함을 보였다. 뜰보리수 분말의 무첨가군에서 환원당 함량 은 $5.01 \mathrm{~g} / 100 \mathrm{~g}$ 으로 가장 높았으며, 뜰보리수 분말 $3 \%$

Table 4. Soluble protein and reducing sugar contents of Elaeagnus multiflora powder and 'Sulgidduk' added with Elaeagnus multiflora powder

\begin{tabular}{ccc}
\hline $\begin{array}{c}\text { 'Sulgidduk' added } \\
\text { with Elaeagnus } \\
\text { multiflora powder }{ }^{1)}\end{array}$ & $\begin{array}{c}\text { Soluble protein } \\
(\mathrm{g} / 100 \mathrm{~g})\end{array}$ & $\begin{array}{c}\text { Reducing sugar } \\
(\mathrm{g} / 100 \mathrm{~g})\end{array}$ \\
\hline SEP0 & $0.12 \pm 0.00^{2) \mathrm{e} 3)}$ & $5.01 \pm 0.01^{2) \mathrm{a} 3)}$ \\
SEP3 & $0.16 \pm 0.01^{\mathrm{d}}$ & $4.16 \pm 0.01^{\mathrm{b}}$ \\
SEP6 & $0.25 \pm 0.01^{\mathrm{c}}$ & $4.11 \pm 0.00^{\mathrm{c}}$ \\
SEP9 & $0.37 \pm 0.00^{\mathrm{b}}$ & $4.00 \pm 0.01^{\mathrm{d}}$ \\
SEP12 & $0.52 \pm 0.01^{\mathrm{a}}$ & $3.75 \pm 0.00^{\mathrm{e}}$ \\
$\begin{array}{c}\text { Elaeagnus multiflora } \\
\text { powder }\end{array}$ & $2.31 \pm 0.01$ & $5.48 \pm 0.01$ \\
\hline
\end{tabular}

${ }^{1)}$ See the preparation formulas for 'Sulgidduk' in Table 1 .

${ }^{2}$ A) All value are expressed as Mean $\pm \mathrm{SD}$ of triplicate determinations.

${ }^{3)}$ Different superscripts letters within the column are significantly different at $\mathrm{p}<0.05$ by Duncan`s multiple range test. 
첨가군에서는 $4.16 \mathrm{~g} / 100 \mathrm{~g}$, 뜰보리수 분말 $6 \%$ 첨가군에서 는 $4.11 \mathrm{~g} / 100 \mathrm{~g}$, 뜰보리수 분말 $9 \%$ 첨가군에서는 $4.00 \mathrm{~g} / 100$ $\mathrm{g}$, 뜰보리수 분말 $12 \%$ 첨가군에서는 $3.75 \mathrm{~g} / 100 \mathrm{~g}$ 으로 환원 당 함량이 낮았다. $\operatorname{Kim}(2004)$ 은 환원당에 의한 비효소적 glycosylation(Maillard reaction)은 단백질을 중합시킬 뿐 아 니라 아미노산 잔기를 크게 손상시킨다고 보고했으며, 이 는 환원당의 종류에 따른 차이가 있었다고 하였다. 또한, 식품내에서 가열에 의해 식품의 변화를 초래할 뿐만 아니 라 식품 가공 중 향미 생성에도 영향을 미치는 것으로 보고하였다. 따라서 본 연구의 뜰보리수 분말 첨가량에 따른 설기떡의 환원당 함량이 감소하는 결과는 뜰보리수 분말을 첨가한 설기떡의 당 종류에 따른 함량 등 보다 구체적인 연구가 필요한 것으로 생각된다.

\section{색도}

뜰보리수 분말의 첨가량을 달리하여 제조한 설기떡의 색도 측정 결과는 Table 5 와 같다. 색도 측정 결과 명도인 L값은 뜰보리수 무첨가군에서 84.39로 가장 높게 나타났 으며, 뜰보리수 분말 $3 \%$ 첨가군은 78.14 , 뜰보리수 분말 $6 \%$ 첨가군은 73.31 , 뜰보리수 분말 $9 \%$ 첨가군은 70.27 , 뜰보리수 분말 $12 \%$ 첨가군은 66.25 로 뜰보리수 분말 첨가 량이 증가할수록 설기떡의 $\mathrm{L}$ 값은 감소함을 보였다. 이러 한 결과는 $\mathrm{Kim}$ 등(2013)의 산수유 분말을 첨가한 설기떡, Park 등(2002)의 클로렐라를 첨가한 백설기 품질특성 연구 에서와 같이 일반적으로 부재료를 첨가시 부재료의 색감 으로 인해 명도가 감소하였다는 결과와 같았다. 적색도를 나타내는 a값은 뜰보리수 무첨가군에서 2.24 , 뜰보리수 분말 $3 \%$ 첨가군에서 10.81 , 뜰보리수 분말 $12 \%$ 첨가군에 서는 16.20 으로 뜰보리수 분말을 첨가할수록 a값은 증가함 을 보였다. 황색도를 나타내는 $\mathrm{b}$ 값은 뜰보리수 분말 무첨 가군에서 3.84 로 가장 낮았으며, 뜰보리수 분말 $3 \%$ 첨가한 첨가군에서 16.92 , 뜰보리수 분말 $12 \%$ 첨가군에서는 28.04
로 뜰보리수 분말을 첨가할수록 황색도는 증가하는 경향 을 보였다. 이러한 결과는 Rha와 $\operatorname{Kang}(2014)$ 이 연구한 복분 자 잎 분말첨가 설기떡 연구에서 복분자 잎 분말 첨가량에 따라 설기떡의 색도에 영향을 준 것으로 보고하였고, Choi 와 Choi(2018)가 연구한 꾸지뽕열매 동결건조 분말을 첨가 한 설기떡의 품질특성 연구에서도 꾸지뽕 열매의 붉은 색 감이 설기떡의 색도에도 영향을 미친 것으로 보여진 결과 와 유사하게 뜰보리수 열매의 붉은색이 뜰보리수 설기떡 색도에도 영향을 미친 것으로 생각된다.

\section{조직감 측정}

뜰보리수 분말 첨가량을 달리한 설기떡의 조직감 측정 결과는 Table 6과 같다. 경도는 뜰보리수 무첨가군이 0.92 $\mathrm{kg} / \mathrm{cm}^{2}$ 로 가장 높았으며, 뜰보리수 분말 $3 \%$ 첨가군은 0.78 $\mathrm{kg} / \mathrm{cm}^{2}$, 뜰보리수 분말 $6 \%$ 첨가군은 $0.73 \mathrm{~kg} / \mathrm{cm}^{2}$, 뜰보리수 분말 $9 \%$ 첨가군은 $0.66 \mathrm{~kg} / \mathrm{cm}^{2}$, 뜰보리수 분말 $12 \%$ 첨가군 은 $0.58 \mathrm{~kg} / \mathrm{cm}^{2}$ 로 뜰보리수 분말 첨가량이 증가할수록 경도 는 감소함을 보였다. 이러한 결과는 Shin 등(2009)이 연구 한 홍삼분말을 첨가한 설기떡의 품질특성에 관한 연구에 서 홍삼분말 첨가량이 증가할수록 설기떡의 경도는 감소 하는 경향을 나타내었고, Yoon(2007)이 연구한 연잎가루 를 첨가한 설기떡의 품질특성 연구에서 연잎가루 첨가량 이 증가할수록 설기떡의 경도는 낮아져 본 연구 결과와 유사하였다. 부착성은 뜰보리수 분말 무첨가군에서 38.32 $\mathrm{g}$ 으로 가장 높게 나타났고, 뜰보리수 분말 첨가량이 증가 할수록 전체적으로 $22.38-26.15 \mathrm{~g}$ 으로 다소 감소함을 보 였다. 응집성은 뜰보리수 분말 무첨가군에서 $58.03 \%$ 로 가 장 높게 나타났고, 뜰보리수 분말 첨가량이 증가할수록 전체적으로 $52.28-54.25 \%$ 로 다소 감소함을 보였다. 탄력 성은 뜰보리수 분말 무첨가군에서 $66.22 \%$ 로 가장 낮게 나타났고, 뜰보리수 분말 첨가량이 증가할수록 탄력성은 전체적으로 $62.55-69.19 \%$ 로 다소 증가함을 보였다. 씹힘

Table 5. Hunter's color value of 'Sulgidduk' added with Elaeagnus multiflora powder

\begin{tabular}{cccc}
\hline $\begin{array}{c}\text { 'Sulgidduk' added } \\
\text { with Elaeagnus } \\
\text { multiflora } \text { powder }\end{array}$ & \multicolumn{3}{c}{ Hunter's color value } \\
\hline & $\mathrm{L}$ & $\mathrm{a}$ & $\mathrm{b}$ \\
\hline SEP0 & $84.39 \pm 0.12^{2) \mathrm{a} 3)}$ & $2.24 \pm 0.01^{\mathrm{e}}$ & $3.84 \pm 0.08^{\mathrm{e}}$ \\
SEP3 & $78.14 \pm 0.42^{\mathrm{b}}$ & $10.81 \pm 0.01^{\mathrm{d}}$ & $16.92 \pm 0.04^{\mathrm{d}}$ \\
SEP6 & $73.31 \pm 0.21^{\mathrm{c}}$ & $12.56 \pm 0.04^{\mathrm{c}}$ & $21.17 \pm 0.03^{\mathrm{c}}$ \\
SEP9 & $70.27 \pm 0.27^{\mathrm{d}}$ & $14.03 \pm 0.02^{\mathrm{b}}$ & $25.05 \pm 0.02^{\mathrm{b}}$ \\
SEP12 & $66.25 \pm 0.30^{\mathrm{e}}$ & $16.20 \pm 0.02^{\mathrm{a}}$ & $28.04 \pm 0.03^{\mathrm{a}}$ \\
\hline
\end{tabular}

${ }^{1)}$ See the preparation formulas for 'Sulgidduk' in Table 1.

${ }^{2)}$ All value are expressed as Mean $\pm \mathrm{SD}$ of triplicate determinations.

${ }^{3)}$ Different superscripts letters within the column are significantly different at $\mathrm{p}<0.05$ by Duncan`s multiple range test. 
Table 6. Textural properties of 'Sulgidduk' added with Elaeagnus multiflora powder

\begin{tabular}{cccccc}
\hline $\begin{array}{c}\text { Sulgidduk' added } \\
\text { with Elaeagnus } \\
\text { multiflora powder }{ }^{1)}\end{array}$ & $\begin{array}{c}\text { Hardness } \\
\left(\mathrm{kg} / \mathrm{cm}^{2}\right)\end{array}$ & $\begin{array}{c}\text { Adhesiveness } \\
(\mathrm{g})\end{array}$ & $\begin{array}{c}\text { Cohesiveness } \\
(\%)\end{array}$ & $\begin{array}{c}\text { Texture parameters } \\
(\%)\end{array}$ & $\begin{array}{c}\text { Chewiness } \\
(\mathrm{kg})\end{array}$ \\
\hline SEP0 & $0.92 \pm 0.02^{2) \mathrm{a} 3)}$ & $38.32 \pm 0.03^{\mathrm{a}}$ & $58.03 \pm 0.04^{\mathrm{a}}$ & $66.22 \pm 0.03^{\mathrm{c}}$ & $0.58 \pm 0.05^{\mathrm{a}}$ \\
SEP3 & $0.78 \pm 0.09^{\mathrm{b}}$ & $26.15 \pm 0.04^{\mathrm{b}}$ & $54.25 \pm 0.01^{\mathrm{b}}$ & $62.55 \pm 0.03^{\mathrm{e}}$ & $0.46 \pm 0.05^{\mathrm{b}}$ \\
SEP6 & $0.73 \pm 0.05^{\mathrm{bc}}$ & $25.25 \pm 0.02^{\mathrm{c}}$ & $54.01 \pm 0.05^{\mathrm{c}}$ & $65.00 \pm 0.07^{\mathrm{d}}$ & $0.41 \pm 0.05^{\mathrm{bc}}$ \\
SEP9 & $0.66 \pm 0.06^{\mathrm{bc}}$ & $23.72 \pm 0.04^{\mathrm{d}}$ & $53.71 \pm 0.04^{\mathrm{d}}$ & $67.38 \pm 0.03^{\mathrm{b}}$ & $0.37 \pm 0.07^{\mathrm{bc}}$ \\
SEP12 & $0.58 \pm 0.03^{\mathrm{c}}$ & $22.38 \pm 0.03^{\mathrm{e}}$ & $52.28 \pm 0.03^{\mathrm{e}}$ & $69.19 \pm 0.05^{\mathrm{a}}$ & $0.31 \pm 0.04^{\mathrm{c}}$ \\
\hline
\end{tabular}

${ }^{1)}$ See the preparation formulas for 'Sulgidduk' in Table 1.

${ }^{2)}$ All value are expressed as Mean $\pm \mathrm{SD}$ of triplicate determinations.

${ }^{3)}$ Different superscripts letters within the column are significantly different at $\mathrm{p}<0.05$ by Duncan`s multiple range test.

성은 뜰보리수 분말 첨가량이 증가할수록 $0.31-0.46 \mathrm{~kg}$ 으 로 감소함을 보였다. 이러한 조직감 측정 결과를 종합해보 면 뜰보리수 분말의 첨가량이 증가할수록 설기떡은 부드 러운 질감을 나타내는 것을 알 수 있었다.

\section{폴리페놀 함량과 전자공여능}

뜰보리수 분말과 뜰보리수 분말 첨가량을 달리한 설기 떡의 총 폴리페놀 함량 및 전자공여능 측정 결과는 Table 7 과 같다. 뜰보리수 분말의 총 폴리페놀 함량은 1077 $\mathrm{mg} / 100 \mathrm{~g}$ 이었고, 뜰보리수 설기떡의 총 폴리페놀 함량은 뜰보리수 분말 무첨가군에서 $0.52 \mathrm{mg} / 100 \mathrm{~g}$, 뜰보리수 분말 $3 \%$ 첨가군은 $5.49 \mathrm{mg} / 100 \mathrm{~g}$, 뜰보리수 분말 $6 \%$ 첨가군은 $7.13 \mathrm{mg} / 100 \mathrm{~g}$, 뜰보리수 분말 $9 \%$ 첨가군은 $9.45 \mathrm{mg} / 100 \mathrm{~g}$, 뜰보리수 분말 $12 \%$ 첨가군은 $12.11 \mathrm{mg} / 100 \mathrm{~g}$ 으로 뜰보리수 분말 첨가량이 증가할수록 뜰보리수 설기떡의 총 폴리페 놀 함량도 증가함을 보였다. 이와 같은 결과는 뜰보리수 열매의 총 폴리페놀 함량이 높게 나타나, 뜰보리수 분말 첨가량이 증가할수록 설기떡의 총 폴리페놀 함량도 높아 진 것으로 생각된다. 또한, $\mathrm{Yu}$ 등(2017)이 연구한 아몬드
첨가 설기떡에서 아몬드 첨가량이 증가할수록 설기떡의 총 폴레페놀 함량은 증가하였고, $\operatorname{Ahn}(2019)$ 이 연구한 쑥 분말을 첨가한 설기떡 결과에서도 쑥 첨가량이 증가할수 록 설기떡의 총 폴리페놀 함량이 증가했음을 알 수 있었다.

뜰보리수 설기떡 제조에 첨가한 뜰보리수 분말의 전자 공여능 측정 결과 $72.80 \%$ 이었다. 뜰보리수 설기떡의 전자 공여능을 측정한 결과에서는 뜰보리수 분말 무첨가군에 서 $24.75 \%$ 로 뜰보리수 분말 첨가군보다 전자공여능은 낮 았고, 뜰보리수 분말의 첨가량이 증가할수록 뜰보리수 설 기떡의 전자공여능은 전체적으로 $30.15-45.91 \%$ 로 증가 함을 보였다. 이러한 결과는 뜰보리수 열매가 가지고 있는 전자공여능 효과가 뜰보리수 분말 첨가량에 따른 설기떡 의 전자공여능 결과에도 영향을 준 것으로 생각된다. 전자 공여능은 활성 라디칼에 전자를 공여하여 식품 중의 지방 질 산화를 억제하는 목적으로 사용되고 있을 뿐만 아니라 인체 내에서 활성 라디칼에 의한 노화를 억제하는 작용의 목적으로 이용되고 있어(Kim, 2004) 뜰보리수 분말을 첨가 한 설기떡의 전자공여능은 우수하여 식품 중의 지방질 산화 및 노화를 억제하는 척도로 이용할 수 있고, 기능성

Table 7. Total polyphenol content and electron donating ability of Elaeagnus multiflora powder and 'Sulgidduk' added with Elaeagnus multiflora powder

\begin{tabular}{|c|c|c|c|c|c|c|}
\hline & \multirow{2}{*}{$\begin{array}{c}\text { Elaeagnus } \\
\text { multiflora powder }\end{array}$} & \multicolumn{5}{|c|}{ 'Sulgidduk' added with Elaeagnus multiflora powder' } \\
\hline & & SEP0 & SEP3 & SEP6 & SEP9 & SEP12 \\
\hline $\begin{array}{l}\text { Total polyphenol content } \\
(\mathrm{mg} / 100 \mathrm{~g})\end{array}$ & $1077 \pm 0.03^{2)}$ & $0.52 \pm 0.04^{\mathrm{e} 3)}$ & $5.49 \pm 0.12^{\mathrm{d}}$ & $7.13 \pm 0.06^{\mathrm{c}}$ & $9.45 \pm 0.31^{\mathrm{b}}$ & $12.11 \pm 0.06^{\mathrm{a}}$ \\
\hline $\begin{array}{c}\text { Electron donating ability } \\
(\%)\end{array}$ & $72.80 \pm 0.01$ & $24.75 \pm 0.07^{\mathrm{e}}$ & $30.15 \pm 0.14^{\mathrm{d}}$ & $33.02 \pm 0.10^{\mathrm{c}}$ & $39.72 \pm 0.12^{\mathrm{b}}$ & $45.91 \pm 0.01^{\mathrm{a}}$ \\
\hline
\end{tabular}

${ }^{1)}$ See the preparation formulas for 'Sulgidduk' in Table 1.

${ }^{2)}$ All value are expressed as Mean $\pm \mathrm{SD}$ of triplicate Determinations.

${ }^{33}$ Different superscripts letters within the row are significantly different at $\mathrm{p}<0.05$ by Duncan`s multiple range test. 
식품으로서의 개발 가능성이 클 것으로 기대된다.

\section{요 약}

본 연구는 다양한 생리활성을 지닌 뜰보리수 열매를 이용 하여 쌀가루 대비 뜰보리수 분말의 첨가량을 $0 \%, 3 \%, 6 \%$, $9 \%, 12 \%$ 로 설기떡을 제조한 후, 일반성분 함량, $\mathrm{pH}$ 및 당도, 수용성 단백질, 환원당 함량, 색도, 조직감, 총 폴리페놀 함량 및 전자공여능을 측정하여 뜰보리수 설기떡의 품질특성과 항산화 활성을 측정함으로써 설기떡의 기능성 향상과 국민 건강에 이바지함은 물론 뜰보리수의 식품소재로서의 활용도 를 높이는데 기초자료로 활용하고자 연구하였다. 뜰보리수 분말 첨가량에 따른 설기떡의 일반성분을 분석한 결과, 수분 함량은 $39.12-42.53 \%$ 로 뜰보리수 분말의 첨가량이 증가할 수록 수분함량은 증가함을 보였고, 탄수화물 함량은 뜰보리 수 분말 첨가량이 증가할수록 감소함을 보였으며, 조지방과 조회분 함량은 뜰보리수 분말의 첨가량이 증가할수록 증가 함을 보였으나 유의적인 차이는 보이지 않았다. 뜰보리수 설기떡의 $\mathrm{pH}$ 는 뜰보리수 첨가량이 증가할수록 감소함을 보 였고, 당도는 뜰보리수 첨가량이 증가할수록 증가함을 보여 뜰보리수 분말 $12 \%$ 첨가군에서는 $11.03{ }^{\circ} \mathrm{Brix}$ 이었다. 수용성 단백질 함량은 $0.10-0.52 \mathrm{~g} / 100 \mathrm{~g}$ 으로 뜰보리수 분말 무첨가 군에 비해 뜰보리수 분말 첨가량이 증가할수록 수용성 단백 질 함량도 증가함을 보였고, 환원당 함량은 뜰보리수 분말 무첨가군에서 $5.12 \mathrm{~g} / 100 \mathrm{~g}$ 으로 가장 높았고, 뜰보리수 분말 첨가량이 증가할수록 환원당 함량은 감소함을 보였다. 뜰보 리수 분말 첨가 설기떡의 색도 측정 결과, 명도 $\mathrm{L}$ 값은 뜰보리 수 분말 첨가량이 증가할수록 명도값이 감소함을 보였고, 적색도를 나타내는 $\mathrm{a}$ 값과 황색도 $\mathrm{b}$ 값은 뜰보리수 분말을 첨 가할수록 증가하는 경향을 보였다. 뜰보리수 설기떡의 조직 감 측정 결과에서는 뜰보리수 분말 첨가량이 증가할수록 설 기떡의 경도와 부착성, 응집성, 씹힘성은 감소하는 경향을 보였고, 탄력성은 증가함을 보였다. 총 폴리페놀 함량은 뜰보 리수 분말 첨가량이 증가할수록 증가함을 보여 뜰보리수 분 말 $12 \%$ 첨가 설기떡의 총 폴리페놀 함량은 $12.11 \mathrm{mg} / 100$ $\mathrm{g}$ 으로 가장 높았다. 전자공여능은 뜰보리수 무첨가군에서 $24.75 \%$ 로 가장 낮았고, 뜰보리수 분말의 첨가량이 증가할수 록 전자공여능은 증가함을 보여 뜰보리수 분말 $12 \%$ 첨가 설기떡에서 $45.91 \%$ 로 가장 높았다. 이상의 결과로 종합하여 볼 때 동결 건조한 뜰보리수 분말을 첨가하여 제조한 설기떡 은 식품으로서 가치가 높을 것으로 판단되며, 향후 뜰보리수 를 이용한 다양한 제품 개발 가능성에 있어 건강기능성 식품 소재로 활용 가능성이 높을 것으로 생각된다.

\section{Conflict of interests}

The authors declare no potential conflict of interest.

\section{ORCID}

Ju-Yeon Hong

Wang-Kyu Oh

https://orcid.org/0000-0001-5441-8953

https://orcid.org/0000-0003-3545-5075

\section{References}

Ames BN, Saul RL. Oxigen radicals and human disease. Ann Inter Med, 107, 526-545 (1987)

AOAC. Official Methods Analysis 13th ed. Association of Official Analytical Chemists, Washington DC, USA, p 125-132 (1990)

Ahn GJ. Quality characteristics and antioxidantive actives of Sulgidduk added mugwort powder. Culi Sci Hos Res, 25, 184-193 (2019)

Blois ML. Antioxidant determination by the use of a stable free radical. Nature, 181, 1199-1224 (1958)

Cho MS. Korean Tree Illustrations. Academy Publishing Co, Seoul, Korea, p 372 (1989)

Cha GH, Lee HG. Sensory physicochemical characteristics and storage time of Daechu-In-jeulmi added with various levels of chopping jujube. Korean J Soc Food Sci, 17, 29-42 (2001)

Choi SN, Choi EH. Quality characteristics of Sulgidduk with Cudrania tricuspidata fruit freeze drying powder. Food Ser Ind J, 14, 131-139 (2018)

Ham SS, Lee SY, Oh DH, Kim SH, Hong JG. Development of beverages drinks using mountain edible herbs. J Korean Soc Food Sci Nutr, 26, 92-97 (1997)

Hyun YH, Hwang YK, Lee YS. Quality characteristics of Sulgidduk with tapioca flour. Korean J Food Nutr, 18, 103-108 (2005)

Hong JY. A study on the components and physiological activity of Elaeagnus multiflora Thunb. Ph D Thesis, Daegu Haany University, Korea, p 109-111 (2008)

Jan SY, Kim MH, Hong GJ. Quality changes of Sulgidduk added cheonnyuncho (Oputia humifusa) fruit powder during storage. Korean J Soc Food Cookery Sci, 29, 501-509 (2013)

Joung HS. Quality characteristics of paeksulgi added powder of Opuntia ficus indica var. saboten. Korean J Food Cookery Sci, 20, 637-642 (2004)

Kim GY, Moon HK, Lee SW. Quality characteristics of Sulgidduk prepared by addition of astringent persimmon powder. Korean J Food Preserv, 13, 697-702 (2006)

Kim HK, Jin HH, Lee MS, Lee SJ. Quality characteristics 
of Sulgidduk added with Corni fructus powder. Food Eng Prog, 17, 105-111 (2013)

Kim SL. Antioxidant activity and analsis on the components of the fruit of Elaeagnus multiflora Thnmb. MS Thesis, Yeungnam University, Korea, p 34-35 (2004)

Ko KS, Jeon ES. Wild Plants of Korea. Iljinsa, Seoul, Korea, p 454-455 (2003)

Ko SH, Jeong HC. Quality characteristics of redbeet powder and Sulgidduk by redbeet powder of different ratios. Culi Sci Hos Res, 24, 13-21 (2018)

Lim JH. Quality characteristics of Sulgidduk prepared with apple powder. Korean J Food Cookery Sci, 27, 111-123 (2011)

Lee JS, Cho MS, Hong JS. Quality characteristics of Sulgidduk containing added tomato powder. Korean J Food Cookery Sci, 24, 375-381 (2008)

Lee SH. Quality characteristics of Sulgidduk with different additions of deodeok powder. Culi Sci Hos Res, 25, 176-183 (2019)

Lowry OH, Rosebrough NJ, Farr AL, Randall RJ. Protein measurement with the Folin phenol reagent. J Biol Chem, 193, 265-275 (1951)

Nelson NA. A photometric adoption of the somogi method for determination of glucose. J Biol Chem, 153, 375-381 (1944)

Park ID. Effects of Cucurbita maxima duchesne puree on quality characteristics of pound and sponge cakes. Korean J Food Culture, 23, 748-754 (2008)

Park JH. Medicinal Plants of Korea. Shinilbooks, Seoul, Korea, p 953-954 (2004)

Park MK, Lee JM, Park CH, In MJ. Quality characteristics of Sulgidduk containing chlorella powder. J Korean Soc Food Sci Nutr, 31, 225-229 (2002)
Park SY, Kim JW. Screening and isolation of the antitumor agents from medicinal plants ( I ). Kor J Pharmacogn, 23, 264-267 (1992)

Rha YA, Kang BN. Quality evaluation of Sulgidduk added with Rubus coreanus Miquel leaf powder. Culi Sci Hos Res, 20, 128-135 (2014)

Ryu GH, Park JY, Koo BY, Song DS, Lim MS. Korean Rice Cake for Manufactor and Process Engineer. Hyoil Publishers, Seoul, Korea, p 13 (2005)

Seo KM, Chung YH. Quality characteristics of Sulgidduk added with turmeric powder. J East Asian Soc Dietary Life, 24, 201-207 (2014)

Shin MH, Chung NY. Quality evaluation of brown rice Sulgidduk added with fermented black rice bran powder. Food Ser Ind J, 14, 41-50 (2018)

Shin SM, Jung JS, Han MR, Kim AJ, Kim YH. Quality characteristics of Sulgidduk containing added red ginseong powder. Korean J Food and Cookery Sci, 25, 586-592 (2009)

Singleton VL, Rossi JA. Colorimetry of total phenolics with phosphomolybdic -phosphotungstic acid reagents. Am J Enol Vitic, 16, 144-158 (1965)

Yoon SJ. Quality characteristics of Sulgidduk added with lotus leaf powder. Korean J Food Cookery Sci, 23, 433-442 (2007)

Yu HN, Song JH, Kim MR. Quality characteristics and antioxidant activities of Sulgidduk added with almond powder. J Korean Soc Food Sci Nutr, 46, 809-815 (2017)

Yu MH, Im HG, Lee HJ, Ji YJ, Lee IS. Components and their antioxidative activities of methanol extracts from sarcocarp and seed of Zizyphus jujuba var. inermis Rehder. Korean J Food Sci Tech, 38, 128-134 (2006) 